\title{
Qualitative Analysis of the Student Industrial Work Experience Scheme (SIWES) in Tertiary Institutions in Ogun State, Nigeria
}

\author{
Dare O. Omonijo ${ }^{1}$ \\ Michael C. Anyaegbunam ${ }^{2}$ \\ Samuel I. Ejoh ${ }^{3}$ \\ Joe-Akunne Chiamaka Ogechukwu ${ }^{4}$ \\ ${ }^{1}$ Department of Student Industrial Work Experience Scheme, Covenant University, Ota I \\ Department of Sociology Olabisi Onabanjo University, Ago-Iwoye, Nigeria \\ ${ }^{2}{ }_{4}$ Dept. of Psychology, Nnamdi Azikiwe University, Awka, Nigeria, \\ ${ }^{3}$ Department of Biological Sciences, Covenant University, Ota, Nigeria
}

DOI: https://doi.org/10.36941/jesr-2020-0o77

\section{Abstract}

This study was carried out to appraise SIWES in sixteen (16) tertiary institutions in Ogun State, Southwest Nigeria using descriptive method. Among other things, it investigated the percentage of SIWES unit in tertiary institutions in the state that has: (i) a structure; (ii) budget; (iii) coordinators' tenure of office; and (v) a succession plan for coordinators. The study engaged a purposive sampling technique to select one participant from each institution and used descriptive statistics to analyze the data. These include frequency distribution, percentage and ranking. The study among other things concluded that $13(81.3 \%)$ tertiary institutions had SIWES structure while 03(19.7\%) did not have; 5(31.2\%) tertiary institutions had SIWES budget while the majority-11(68.8\%) did not have; 5(31.2\%) tertiary institutions had SIWES coordinators tenure of office while the majority-11(68.8\%) did not have. The study also concluded that no institution (o\%) had a succession plan for SIWES coordinators. Based on its findings, recommendations are made to improve the SIWES unit in higher education systems in the state.

Keywords: Appraisal, SIWES, tertiary institutions, qualitative approach

\section{Introduction}

In developed nations, studies have shown that institutions or organisations, such as tertiary institutions, are being run with certain features (Jyostana 2019; Nitin, 2019; Obi-Anike, Okafor and Adeleke, 2020; Saengchai, Joemsittiprasert and Jermsittiparsert, 2020). Such features include a viable structure that defines the position and roles of personnel in the unit; the number of workers in each unit, a budget that shows the expenditure and income. Others are tenure of office of key personnel, the succession plan for them and attendance in meetings (local, regional and national). These features to some extent could exert influence on the attainment of institutional or organizational goals. Therefore, the importance of each of them cannot be gainsaid most especially in educational systems created to train manpower for national development. 
Despite of the importance of these features in any organisation, literature emanating from developing countries have shown their non-existence in many institutions (Adewuyi and Okemkinde, 2013). This may not be divorced from the poor economy which could hinder adequate funding of organisations. Since such features are usually run by funds and the Chief Executive Officers (CEO) of such institutions might want to minimize cost for maximum profit, not minding the negative implication it portends on the efficient and effective running of organizations. Better still, the nonexistence of such features could be attributed to the menace of corruption in developing countries as resources meant for building those features are been embezzled.

Tertiary institutions are notable educational institutions set up to train workers for impactful social relations, governance, production of goods and services, for home consumption and exportation, to boost foreign exchange earnings. However, the extent to which qualified workers are produced in tertiary institutions depends on the attention they receive from the government $\mathrm{n}$ term of funding and effective management. While educational institutions are well funded in developed nations, literature has shown that they are poorly funded in developing countries (Adewuyi and Okemkinde, 2013). This explains why developed nations economy is highly developed Atchoarena (1995) while that of many developing countries, including Nigeria is yet to find its footing. If the economy of a country is poor, it could impact negatively on her educational systems in terms of provision of state-of-the-art facilities Olowu, Ijeoma and Vanroose (2019), conducive environment, remunerations and conditions of service. It could prompt the brain drain and a dearth of manpower. Thus, studies have shown that competent faculty and staff available usually seek greener pasture abroad to salvage their careers and to earn good remuneration Mahmood, (2017) to perform sociological obligations in their respective families and communities (Omonijo, Olujobi, Anyaegbunam and Adeleke, 2018) etc.

Consequently, studies have shown that quality education is a challenge in many of those countries Odukoya, Omonijo, Olowookere, John \& Atayero, (2019) and that it has greatly resulted in unemployment (Onoyase, 2019). The term quality means excellence Meratwal \& Shanmugapriya, (2019) and when excellence is combined with education, it becomes educational excellence, which is expected to produce competent or quality manpower to manage the affairs of all institutions that constitute a society (Sheoran \& Amita 2019). In Nigeria, quality education has become a major problem in all disciplines for several decades Edike (2014), but it could be observed that its seriousness is more critical in sciences and engineering discourses than social and behavioural sciences, arts and humanities. This is because graduates in social and behavioural sciences deal with papers, human and financial management while those in sciences and engineering deal with human lives and machines for the production of goods and services (Adewuyi and Okemkinde 2013)

Besides, errors made in social and behavioural sciences could easily be corrected while errors made in the science and engineering programmes could be too costly to human existence. In such disciplines, complex machines are used for the production of goods and services, and such machines are expected to be handled by experts in their fields. Any mistake in the process of handling those machines could lead to loss of lives in the chain of production. Besides, scientists usually handle consumable products such as beverages and foods which are necessary for human existence and each stage of the production needs to be properly handled by competent manpower to ensure that the content of products under production is well-produced and packaged, failure of which can result in the production of substandard products that are detrimental to the public or consumers.

The seriousness of poor proficiency of most Nigerian graduates at work has prompted studies in higher educational systems (Akanmu, 2011; Asuquo and Agboola, 2014) without any solution to the extent that its persistence has become a major concern for many employers of labour Pandey (2019), due to the dire need for competent manpower to man the nation's economy (Ifejika, Odunze, Ayanda and Sado, 2008; Ukwueze, 2011). For instance, since independence in 1960, Nigeria is yet to have functioning refineries to refine the abundance of crude oil available in the country, despite producing graduates in chemical, petroleum, electrical and electronic engineering regularly from the polytechnics and universities. Instead, the Nigerian government export crude oil to developed 
countries and purchase refine products for home consumption at a higher price. This could be regarded as an insult to knowledge and the collective thinking of Nigerians. To worsen the situation, the elites in government are indifferent to the practice of exporting crude oil for the purchase of refined products at a higher price for home consumption. Probably, the poor quality of education in the country must have prevented the elite class from realizing that the act or practice, either for their selfish interest, is a disgrace to knowledge and an obstacle to national development.

This is because, education could be regarded as the light that illuminates the darkness; thus, the potency of light could be sufficient enough to disarmed darkness that hinders environmental brightness for peoples free movement. But if the light is not shining brightly, it could prevent people from viewing excellently and the probability of people falling into the ditch could be very bright. With the poor quality of education in Nigeria, therefore, the collective thinking of the elite class must have been prevented from functioning effectively and that could be used to explain why corrupt practices have been accepted as the normal way of life. It could also be used to explain why foreign construction companies such as Julius Berger and Chinese companies have been hitherto saddled with the responsibility of handling major projects such as roads and energy.

In order to address the problem of lack of competency at work after graduation Zunaid, Turner and Jiang, (2020) the nation decided to introduce the Student Industrial Work Experience Scheme (SIWES) with the view of enabling science and engineering students to engage in practical training in industries for six months in the colleges of education and universities and one year for those in the polytechnics Omonijo, Anyaegbunam, Adeleke, Nnatu, Ejor, Oluwunmi, Olowooere and Agubo, (2019). But since its inception, studies have shown that SIWES has not been effective in ensuring proper practical training for interns (Asikogu and Okopu, 2008; Olugbenga, 2009; Ugwuanyi and Ezema, 2010; Mofesola, 2012; Talabi, 2012; Folarin, 2012) but none of these studies focused on institutional factors which could be responsible for the ineffectiveness of SIWES.

Although, the study of Osaikhiuwu, (2014) identified 14 of such institutional factors, which could hinder organizational performance, including academia. These include poor furnished departmental libraries, lack of favourable environment, poor method of delivering lectures, congested lecture room, lack of relevant texts, untimely delivery of reading or reference resources by lecturers, poor system of compiling and retrieving results, poor relationship between student and lecturers, erratic power supply, lack of adequate access to internet facilities, erratic water supply, lack of befitting accommodation and congested examination timetable. These findings could be regarded as viable contributions to the body of knowledge, but the study neglected SIWES as a unit for analysis. The expediency of SIWES in academia cannot be overemphasized because it is a special unit created to oversee student industrial training in tertiary institutions in Nigeria, with the view of ensuring adequate training for students in the course of studentship to enhance their performances at work after graduation.

This gap in knowledge was filled in the study of Wodi and Dokubo (2009) who assesses the extent at which agencies created to manage SIWES operations have been able to achieve their objectives. The study came up with certain hindrances to achieving SIWES objectives. These include failure to sign form 8 and logbooks, inadequate supervision of students on industrial training by the faculty and ITF officials, students failure to get placement on time, unnecessary delay in the payment of students and supervisory allowances by the ITF officials etc.

However, till now, it is evident in the literature that some of the above mentioned problems hinder organisational performance Wodi and Dokubo (2009), but most of these studies were conducted outside the parameters of SIWES structure, budgeting, staff strength, succession planning in the respective institutions. The study as well failed to consider attendance of SIWES personnel at zonal, regional and national meetings and conferences. The strenuous process involved in synthesizing the facts discovered in the literature reinforced the vigorous assortment of the variables in the study. We are very enthusiastic that our results would be extremely creative to both the ITF and the Chief Executives Officers (CEOs) of higher institutions in the state.

The study is divided into three major parts; introduction, methods of data collection and 
analysis. It came out with recommendations on how to improve on the activities of SIWES in tertiary institutions in Ogun State, Nigeria.

\section{Research Questions}

1. What is the percentage of institutions that has SIWES structure?

2. What percentage of institutions has SIWES budget?

3. What percentage of institutions has SIWES coordinator's tenure of office and succession plan?

4. What percentage of institutions had full attendance in zonal and national meetings?

5. Which institution ranks best in coordinators tenure of office?

6. Which institution ranks best in staff strength?

\section{Methods}

Study Design-this study employed ex-posits descriptive design. This is largely attributed to the engagement of data retrieved from the records which could be more accurate than distributing questionnaires which may not reflect solutions to the problem being investigated.

Study Area-This study was carried out in Ogun State, Southwest Geopolitical Zone of Nigeria. The state covers a landmass of $16,409.26$ square kilometers. It is situated between Longitude $3.0^{\circ} \mathrm{E}$ and $5.0^{\circ} \mathrm{E}$ and Latitude $6.2^{\circ} \mathrm{N}$ and $7.8^{\circ} \mathrm{N}$. The state was carved out of the old western Nigeria in February 1976. Presently, Ogun State has a total of 20 Local Government Areas and three Senatorial Districts, (Esther 2015) and it borders Osun and Oyo States in the Northern hemisphere and Lagos in the South. Further to this, the state is bounded in the west by the Republic of Benin and Ondo State in the East (Fiwakemi, 2017). Other popular towns and cities in the state are Sagamu, Ijebu Ode, Ota, Ilaro, Ayetoro, Ogere Remo, Abeokuta etc.

According to the census conducted in 2006, the population of the people of Ogun State was 3,751,140 (Fiwakemi, 2017). Most of these persons work in companies, banking and educational institutions located in the state in order to provide means of livelihood for their families. Some of these companies are cement factories at Ewekoro and Ibese, Nestle plc, Aluminum Rolling Mill, Ota, Apex Paints Ltd, Comstar Manufacturing Company Ltd., Agbara, Geepee Industries Ltd. Ota, Green Tech Industries, Ota and a host of others,

In respect of education, Ogun State has many primary and post-primary institutions, where students have been constantly graduating into tertiary institutions, which are the focus of this study. The state according to the Nigerian Bulletin, (2015) has the highest number of tertiary institutions in Nigeria but sixteen of them were available on the Industrial Training Fund (ITF) list as at the time of this study.

The Population of Study and Sample Size- The tertiary institutions in the state serves as the population of this study. In terms of figure, there are twenty-two tertiary institutions in the state currently but sixteen were available on the list of the Industrial Training Fund (ITF), Abeokuta Area Office, at the time of conducting this study. Due to the nature of the data, SIWES Director / Coordinator in each institution, who are usually one (1) was purposely selected for the study, making sixteen (16).

The Instruments of Data Collection- Secondary source of data collection were engaged. Information supplied by SIWES Director or Coordinator of each institution was retrieved for the study from the 2015 retreat.

As a purely qualitative study, the data used for this study was retrieved from the SIWES retreat of 2016. Simple percentage and ranking were used to analyze the data, where necessary.

Validation and Reliability of Data- The study engaged content analysis to validate the instrument used. Further to that, the instruments were validated by experts in the area of study. Thus, corrections suggested were used to revise the instrument before use. 


\section{Analysis of Research Questions and Discussions}

The $\mathbf{1}^{\text {st }}$ research question investigated the percentage of institutions that has SIWES structure. The result shows the existence of SIWES structure and non-existence in thirteen (13) and (3) institutions respectively. This means the percentage of institutions that had SIWES structure represents $81.3 \%$ while those which did not have constitutes $19.7 \%$ (see Table i)

Table i: SIWES Structure in Tertiary Institutions in Ogun State

\begin{tabular}{|c|c|c|}
\hline SN & Institutions & Availability of SIWES Structure \\
\hline 1 & Federal University & Available \\
\hline 2 & State University & Available \\
\hline 3 & State University of Education & Available \\
\hline 4 & Christian Mission University (a) & Not Available \\
\hline 5 & Christian Mission University (b) & Available \\
\hline 6 & Christian Mission University (c) & Available \\
\hline 7 & Christian Mission University (d) & Available \\
\hline 8 & Muslim Mission University (a) & Available \\
\hline 9 & Private University (a) & Not Available \\
\hline 10 & Private University (b) & Not Available \\
\hline 11 & Federal Polytechnic & Available \\
\hline 12 & State Polytechnics (a) & Available \\
\hline 13 & State Polytechnics (b) & Available \\
\hline 14 & Private Polytechnics (c) & Available \\
\hline 15 & Federal College of Education & Available \\
\hline \multirow[t]{2}{*}{16} & State College of education & Available \\
\hline & Total & $03(19.7 \%)$ \\
\hline
\end{tabular}

\section{Source: SIWES Retreat, (2015)}

The finding in Table $\mathbf{i}$ that structure existed in SIWES unit in $13(81.3 \%)$ institutions out of 16 is commendable, but its nonexistence in $3(19.7 \%)$ institutions is not a welcome development and should be corrected because it could be very difficult to know who occupy different positions in SIWES unit and their job prescriptions or responsibilities per time. It could hinder the smooth running of the scheme in the concerned institutions since the Chartered Quality Institute, (2016) says the structure is an essential element of work organisations that is very vital in running the day-to-day activities of human organisations. Its importance is located in the management of work and how various functions within the organisation are being organized Ashe-Edmundsis, (2017).

Chartered Quality Institute, (2016) also argued that an organization can function without an established structure and that an excellent structure may not ensure results in performance at optimal level, but that could be possible in a simple organizations void of complex division of labour and machinery. Such may not be applicable to tertiary institutions, where competent employees are expected to be raised. In such an organization, lack of structure or working on a wrong structure could hinder ineffectiveness and it goes to corroborate Ashe-Edmundsis (2017), who argues that a poor organizational structure does not only damage workers ability to maximize opportunities, it also engenders problems which can result in chronic financial problems.

The $2^{\text {nd }}$ research question investigated the percentage of institutions that has SIWES budget (see Table ii). 
Table ii: SIWES Budget

\begin{tabular}{cllc}
\hline SN & Institutions & Availability of SIWES Structure \\
\hline $\mathbf{1}$ & Federal University & Available & \\
$\mathbf{2}$ & State University & Available & \\
$\mathbf{3}$ & State University of Education & Available & \\
4 & Christian Mission University (a) & & Not Available \\
5 & Christian Mission University (b) & & Not Available \\
6 & Christian Mission University (c) & & Not Available \\
7 & Christian Mission University (d) & & Not Available \\
8 & Muslim Mission University (a) & & Not Available \\
9 & Private University (a) & & Not Available \\
$\mathbf{1 0}$ & Private University (b) & Available \\
$\mathbf{1 1}$ & Federal Polytechnic & Available \\
$\mathbf{1 2}$ & State Polytechnics (a) & & \\
$\mathbf{1 3}$ & State Polytechnics (b) & & Not Available \\
$\mathbf{1 4}$ & Private Polytechnics (c) & & Not Available \\
$\mathbf{1 5}$ & Federal College of Education & & Not Available \\
$\mathbf{1 6}$ & State College of education & $\mathbf{5 ( 3 1 . 2 \% )}$ & Not Available \\
\hline & Total & & 11(68.8\%)
\end{tabular}

Source: SIWES Retreat, (2015)

The result in Table ii, indicates that only 5(31.2\%) institutions had SIWES budget, while 11(68.8\%) did not have. The implication of not having SIWES budget in 11 institutions could also hinder the effectiveness of the unit because money is needed to supervise the following programmes in the unit:

- Eight (8) weeks Student Work Experience Programme (SWEP). This programme takes place every year among 200 level Engineering students. Materials such as kits, hand gloves, helmets, job suit etc. are to be bought for students. Further to the above, other equipments necessary for students training within this period are expected to be purchased;

- Yearly supervision of 400 level Engineering and 300 level Science students who participate in six (6) months industrial training in industries and organisations every year; and

- Others.

Studies have shown the usefulness of budgeting in every organisation (Peavler 2017). Its importance is hinged on the opportunity it provides in determining the financial statement per time. Thus, in institutions where budget does not exist, accountability may likely be a major problem.

Research question three examined the percentage of institutions that has SIWES coordinator's tenure of office. The result in Table iii shows that five (5) institutions had tenure of office for SIWES coordinators while eleven (11) did not have, which represents $31.2 \%$ and $68.8 \%$ respectively. This shows that majority of SIWES unit in the institution under study did not have tenure office. It means coordinators are appointed to service in the unit without a defined time to spend. Therefore, he could be there for many years without any replacement.

Table iii: Tenure of Office and Succession Plan of Coordinators

\begin{tabular}{|c|c|c|c|}
\hline SN & Institutions & $\begin{array}{c}\text { Tenure of Office for } \\
\text { Coordinators/ Directors }\end{array}$ & $\begin{array}{c}\text { Succession Plan for } \\
\text { Coordinators/ Directors }\end{array}$ \\
\hline 1 & Federal University & Available & Not Available \\
\hline 2 & State University & Available & Not Available \\
\hline 3 & State University of Education & Available & Not Available \\
\hline 4 & Christian Mission University (a) & Not Available & Not Available \\
\hline 5 & Christian Mission University (b) & Not Available & Not Available \\
\hline 6 & Christian Mission University (c) & Not Available & Not Available \\
\hline
\end{tabular}




\begin{tabular}{|c|c|c|c|}
\hline SN & Institutions & $\begin{array}{c}\text { Tenure of Office for } \\
\text { Coordinators/ Directors }\end{array}$ & $\begin{array}{c}\text { Succession Plan for } \\
\text { Coordinators/ Directors }\end{array}$ \\
\hline 7 & Christian Mission University (d) & Not Available & Not Available \\
\hline 8 & Muslim Mission University (a) & Not Available & Not Available \\
\hline 9 & Private University (a) & Not Available & Not Available \\
\hline 10 & Private University (b) & Not Available & Not Available \\
\hline 11 & Federal Polytechnic & Available & Not Available \\
\hline 12 & State Polytechnics (a) & Available & Not Available \\
\hline 13 & State Polytechnics (b) & Not Available & Not Available \\
\hline 14 & Private Polytechnics (c) & Not Available & Not Available \\
\hline 15 & Federal College of Education & Not Available & Not Available \\
\hline \multirow[t]{2}{*}{16} & State College of education & Not Available & Not Available \\
\hline & Total & $11(68.8 \%)$ & $16(100 \%)$ \\
\hline
\end{tabular}

Source: SIWES Retreat, (2015)

In standard organisations, a restriction on the span of office for coordinators or directors or units head is fixed for two main reasons:

- Firstly, there is every likelihood that a coordinator or a director loses the his independence and the external viewpoint which he is expected to bring into office if the tenure of office is not regulated, and

- Secondly, the contribution of a long service coordinator or director may wane and become irrelevant to the institution (Beck and Tunny, 2014).

Table iii also investigated the percentage of institutions that has a succession plan for coordinators. The result shows that none of the 16 institutions has a succession plan for SIWES coordinators, which represents $0 \%$. This means that when the old coordinator leaves the office the new coordinator may not be able to have any foreknowledge of assignments to be carried out. Thus, it could take him or her months to become familiar with SIWES assignments and it may likely hinder effective performance within the period.

Research question 4, intends to investigate the percentage of institutions that had full attendance at zonal and national meetings in the period under study.

Table iv: Institutional Attendance at Zonal and National Meetings in 2016

\begin{tabular}{|c|c|c|c|c|c|}
\hline SN & Institutions & \multicolumn{2}{|c|}{$\begin{array}{l}\text { Attendance at } \\
\text { Zonal Meetings }\end{array}$} & \multicolumn{2}{|c|}{$\begin{array}{c}\text { Attendance at National } \\
\text { Meeting (Biennial } \\
\text { Conference, 2016) }\end{array}$} \\
\hline 1 & Federal University & 4 times & & Present & \\
\hline 2 & State University & 4 times & & Present & \\
\hline 3 & State University of Education & 4 times & & Present & \\
\hline 4 & Christian Mission University (a) & 4 times & & Present & \\
\hline 5 & Christian Mission University (b) & 4 times & & & Absent \\
\hline 6 & Christian Mission University (c) & 4 times & & Present & \\
\hline 7 & Christian Mission University (d) & 4 times & & Present & \\
\hline 8 & Muslim Mission University (a) & 4 times & & Present & \\
\hline 9 & Private University (b) & 4 times & & Present & \\
\hline 10 & Federal Polytechnic & 4 times & & & Absent \\
\hline 11 & State Polytechnics (a) & & 3 times & Present & \\
\hline 12 & State Polytechnics (b) & & 3 times & Present & \\
\hline 13 & Private Polytechnics (c) & & 3 times & & Absent \\
\hline 14 & Federal College of Education & & 3 times & & Absent \\
\hline 15 & State College of education & & 3 times & Present & \\
\hline \multirow[t]{2}{*}{16} & Private University (a) & & 3 times & & Absent \\
\hline & & $10(62.5 \%)$ & $6(37 \cdot 5 \%)$ & $11(68.75 \%)$ & $5(31.25 \%)$ \\
\hline
\end{tabular}

Source: SIWES Retreat, (2015) 
The result in Table iv above shows that SIWES personnel in 10 institutions attended zonal meetings four times, which connotes full representation in the period of study while personnel in 6 institutions attended meetings three times. This represents $(62.5 \%)$ and $(37.5 \%)$ respectively.

Regarding the national meeting, which is the Biennial Conference, a meeting was convened once in the period of study and SIWES officials in 11 institutions were in attendance while their colleagues in 5 institutions failed to attend. This represents (68.75\%) and (31.25\%) respectively. Although, SIWES personnel in most institutions attended meetings in the period under which is commendable, as members of such institutions would be able to access information dispense to move SIWES unit forward. Thus, when members of staff attend meetings they are kept abreast of valuable information for running the organization.

Previous studies have expressed the importance of attending meetings in the workplace (Fuda, 2016). It also assists organizations to accomplish objectives, save money and time (Jamison 2015).

Research question 5 intends to determine the best institution according to the tenure of office by ranking. Based on the result in Table $\mathbf{v}$ below, only five (5) institution was ranked best in term of tenure of office of " $2(1)$ " meaning two years and one term. This is followed by three (3) institutions that were ranked $2^{\text {nd }}$ in term of tenure of office of " $2(2)$, meaning two years and two terms, making four years of tenure for coordinators. One institution was ranked 3 rd based on the tenure of "6(2)", meaning six years and two terms. Lastly, seven (7) institutions that lacked tenure of office were ranked $4^{\text {th }}$.

Table v: Tenure of Office of SIWES Coordinator / Director by Ranking

\begin{tabular}{|c|c|c|c|}
\hline SN & Institutions & Tenure of Office & Rank \\
\hline 1 & Federal University & $2(2)$ & $2^{\text {nd }}$ \\
\hline 2 & State University & $2(2)$ & $2^{\text {nd }}$ \\
\hline 3 & State University of Education & NA & $4^{\text {th }}$ \\
\hline 4 & Christian Mission University (a) & NA & $4^{\text {th }}$ \\
\hline 5 & Christian Mission University (b) & $2(2)$ & $2^{\text {nd }}$ \\
\hline 6 & Christian Mission University (c) & NA & $3^{\text {rd }}$ \\
\hline 7 & Christian Mission University (d) & NA & $3^{\text {rd }}$ \\
\hline 8 & Muslim Mission University (a) & $2(6)$ & $3^{\text {rd }}$ \\
\hline 9 & Private University (a) & NA & $4^{\text {th }}$ \\
\hline 10 & Private University (b) & $2(1)$ & $1^{\text {st }}$ \\
\hline 11 & Federal Polytechnic & $2(1)$ & $1^{\text {st }}$ \\
\hline 12 & State Polytechnics (a) & $2(1)$ & $1^{\text {st }}$ \\
\hline 13 & State Polytechnics (b) & $2(1)$ & $1^{\text {st }}$ \\
\hline 14 & Private Polytechnics (c) & NA & $4^{\text {th }}$ \\
\hline 15 & Federal College of Education & NA & $4^{\text {th }}$ \\
\hline 16 & State College of education & $2(1)$ & $1^{\text {st }}$ \\
\hline
\end{tabular}

\section{Source: SIWES Retreat, (2015)}

Studies have shown the expediency of tenure of office of key holders in work organization Beck and Tunny, (2014). It provides an opportunity for key positions to be rotated among senior members of staff for equity. It could also provide an opportunity for officers who have served to rest and be relieved of heavy assignments. Lastly, it could enable the easy flow of fresh idea from other officers which may assist in achieving organisational goals. 
Table vi: Institutional Staff Strength

\begin{tabular}{|c|c|c|c|}
\hline SN & Institutions & No. of Staff & Rank \\
\hline 1 & Federal University & 5 & $2^{\text {nd }}$ \\
\hline 2 & State University & 5 & $2^{\text {nd }}$ \\
\hline 3 & State University of Education & 2 & $5^{\text {th }}$ \\
\hline 4 & Christian Mission University (a) & 2 & $5^{\text {th }}$ \\
\hline 5 & Christian Mission University (b) & 2 & $5^{\text {th }}$ \\
\hline 6 & Christian Mission University (c) & 2 & $5^{\text {th }}$ \\
\hline 7 & Christian Mission University (d) & 2 & $5^{\text {th }}$ \\
\hline 8 & Muslim Mission University (a) & 3 & $4^{\text {th }}$ \\
\hline 9 & Private University (a) & 2 & $5^{\text {th }}$ \\
\hline 10 & Private University (b) & 2 & $5^{\text {th }}$ \\
\hline 11 & Federal Polytechnic & 4 & $3^{\text {rd }}$ \\
\hline 12 & State Polytechnics (a) & 6 & 1st \\
\hline 13 & State Polytechnics (b) & 2 & $5^{\text {th }}$ \\
\hline 14 & Private Polytechnics (c) & 2 & $5^{\text {th }}$ \\
\hline 15 & Federal College of Education & 2 & $5^{\text {th }}$ \\
\hline 16 & State College of education & 2 & $5^{\text {th }}$ \\
\hline
\end{tabular}

Source: SIWES Retreat, (2015)

The $6^{\text {th }}$ research question was tackled by ranking institutions by staff strength as indicated below:

1. Coordinator, usually an engineer

2. Administrative Officer

3. Higher Executive Officer

4. Typist

5. A driver

6. A messenger

7. Cleaner

The result in Table vi shows that no institution operates on the staff strength of seven (7) persons. However, an institution was ranked best with six (6) persons. This is followed by two (2) institutions that were ranked $2^{\text {nd }}$ with five (5) staff. One (1) institution was ranked $3^{\text {rd }}$ and $4^{\text {th }}$ with four (4) and three (3) members of staff respectively while the remaining eleven (11) institutions were ranked $5^{\text {th }}$ with just two (2) staff.

The result shows poor staffing in SIWES unit in the institutions under study and it could affect the effective and efficient delivery of assignments in the unit. Studies have shown that organisations that experience a shortage of workers will have their workers subjected to heavy workload (Rasool and Botha, 2011; Nag, 2016). The implication lies in workers becoming disgruntled at work and it harms their effectiveness and efficiency in achieving the organisational goals (Nag, 2016).

Since there is a shortage of staff in the SIWES unit, the probability of the unit being able to monitor students on industrial training for proper skill acquisition could be very remote. It takes enough manpower to supervise students on industrial training, collates their data, prepares their letters of placement, getting placement for them in various organisations, submit their master and placement list in the ITF office and national Universities Commission, Abuja.

\section{Strength and Limitations}

Previous studies have shown that every study has its area of strength and weakness. Hence, the present study is not excluded. In that wise, the qualitative approach applied to the study serves as its most significant limitation. The methodology that would have been able to measure the influence of structure, budget, staff strength, tenure of office and succession plan on SIWES effectiveness and 
efficiency would have been better. Also, students, company and institutionally based supervisors would have been included in the study in order to provide a robust study. We hereby leave these flaws for further study

\section{Summary of Major Findings}

The major findings of the study are as follows:

1. $13(81.3 \%)$ tertiary institutions had established SIWES structure while 03(19.7\%) did not have;

2. $5(31.2 \%)$ tertiary institutions had SIWES budget while $11(68.8 \%)$ did not have;

3. $5(31.2 \%)$ tertiary institutions had SIWES coordinators tenure of office while $11(68.8 \%)$ did not have. However, no institution (o\%) had a succession plan for coordinators;

4. $10(62.5 \%)$ higher educational systems had full attendance at the zonal meeting while $6(37.5 \%)$ had three times attendance. With respect to national meeting-biennial conference, representatives of $11(68.75 \%)$ tertiary institutions were in attendance while the representative of $5(31.25 \%)$ institutions were not in attendance;

5. Five (5) institutions were ranked best in term of tenure of office of "2(1)", three (3) institutions that were ranked $2^{\text {nd }}$ with " $2(2)$, meaning two years and two terms, One institution was ranked $3^{\text {rd }}$ with " $6(2)$ ", meaning six years and two terms and seven (7) institutions that lacked tenure of office were ranked $4^{\text {th }}$; and

6. In respect of staff strength, one institution was ranked best with six (6) workers, two (2) institutions that were ranked $2^{\text {nd }}$ with five (5) staff, One (1) institution was ranked $3^{\text {rd }}$ and $4^{\text {th }}$ with four (4) and three (3) members of staff respectively while the remaining eleven (11) institutions were ranked $5{ }^{\text {th }}$ with just two (2) staff.

\section{Conclusion}

Based on the above findings, the study concludes that $13(81.3 \%)$ tertiary institutions had established SIWES structure while 03(19.7\%) did not have. It also concludes that 5(31.2\%) tertiary institutions had SIWES budget while $11(68.8 \%)$ did not have; $5(31.2 \%)$ tertiary institutions had SIWES coordinators tenure of office while $11(68.8 \%)$ did not have. However, no institution $(0 \%)$ had a succession plan for SIWES coordinators; $10(62.5 \%)$ higher educational systems had full attendance at the zonal meeting while $6(37.5 \%)$ had three times attendance. With respect to national meeting-biennial conference, the representatives of $11(68.75 \%)$ tertiary institutions were in attendance while the representatives of $5(31.25 \%)$ institutions were not in attendance. The study also established that five (5) institutions were ranked best in term of tenure of office of " $2(1)$ ", three (3) institutions were ranked 2 nd with " $2(2)$, meaning two years and two terms. Only one institution was ranked 3 rd with " $6(2)$ ", meaning six years and two terms and seven (7) institutions that lacked tenure of office were ranked 4 th

\section{Recommendations}

Based on the above conclusion, the followings are recommended to the Chief Executive of tertiary institutions in the state:

1. Institutions that operate SIWES unit without a structure should set up SIWES structure as soon as possible

2. Any SIWES unit in any tertiary institution that has no budget should set up its budget henceforth

3. Institutions without SIWES tenure of office and succession plan should set up tenure of office and succession plan for effective handover and smooth running of the unit

4. Every institution should consider attendance in meetings as a priority at all levels.

5. SIWES unit in each tertiary institutions should maintain the normal staff strength to ensure effective delivery of assignments. 


\section{Acknowledgments}

This work was supported in the payment of the publication fee by the Covenant University Centre for Research and Innovation Development (CUCRID)

\section{References}

Adeyemi, T. O. (2011). Financing of education in Nigeria: An analytical review. American Journal of Social and Management Sciences. ISSN Print: 2156-1540, ISSN Online: 2151-1559, DOI:10.5251/ajsms.2011.2.3.295.303

Adewuyi, J. O and Okemkinde, T. (2013). Higher education financing in Nigeria: Issues and trends. International Journal of Educational Administration and Policy Studies, 5(7):121-127. DOI: 10.5897/IJEAPS12.033

Akanmu, O. (2011). Graduate Employment and Employability Challenges in Nigeria. This paper was also presented at the British Council Global Higher Education Conference in Hong- Kong, on the $12^{\text {th }}$ of March, 2011. Available on http://olusfile.blogspot.com.ng/2011/o1/putting-nigerian-graduate-to-work.html. Accessed on February 3, 2016

Ashe-Edmundsis, S. (2017). What Is the Impact of Poor Organizational Structure Relative to Growth? Available on < http://smallbusiness.chron.com/impact-poor-organizational- structure-relative-growth-75327.html>

Asikogu, L. O and Okopu, N. P. (2008). Students Industrial Work Experience Scheme (SIWES) In Architecture: The Need for Appropriate Job Specification. AARCHES Journal, 8(1):30-38

Asuquo and Agboola, (2014). Nigerian Universities Outputs and Their Employability in the Labour Markets in South-South, Nigeria. American Journal of Educational Research, 2(12):1244- 1249. DOI:10.12691/education-2$12-18$

Atchoarena, D. (1995). Lifelong learning in Selected Industrialized Countries. International Institute for Educational Planning. National Institute for Educational Research, Tokyo, Japan. UNESCO

Basu, S., Andrews, J., Kishore, S., Panjabi, R., \& Stuckler, D. (2012). Comparative Performance of Private and Public Healthcare Systems in Low and Middle-Income Countries: A Systematic Review. PLoS Medicine, 9(6), e1001244. http://doi.org/10.1371/journal.pmed.1001244

Beck, J and Tunny, J. (2014). Director's Tenure. Milton Qld: Effective Governance Pty Ltd.

Chartered Quality Institute, (2016). The CQI is the only chartered professional body dedicated entirely to quality. Available on http://www.thecqi.org/Knowledge-Hub/Knowledge- portal/Interactions-of-organisations-andpeople/Corporate-structure/. Retrieved on May 20, 2016

Edike, T. (2014). Nigeria: Emphasis on Certificate Major Cause of Decay in Education - Cleric. Available on http://allafrica.com/stories/201408041913.html> Accessed on December 13, 2017

Esther, C. (2015). List of Nigerian Senators and Their Senatorial Districts. Available on https://constative.com/news/current-affairs/list-of-nigerian-senators-and-their- $\quad$ senatorial-districts> Retrieved on September 10, 2017

Fiwakemi, S. (2017). The Geography of Ogun State. Available on http://carenewsng.blogspot.com.ng/2016/o1/geography-of-ogun-state.html>Retrieved on September 10, 2017

Folarin, G. S. (2012). A Technical Report of the Students Industrial Work-Experience Scheme (SIWES). Department of Agricultural Economics and Extension, School of Agriculture and Agricultural Technology. Federal University of Technology (FUTA). Akure.

Fuda, P. (2016). 10 Reasons Why Effective Meetings Are So Important. Available on https://www.huffpost.com/entry/1o-reasons-why-effective_b_6130262

Ifejika, F. C., Odunze, J. O., Ayanda and Sado, V. A. K. (2008). Analysis of Students Industrial Work Experience Scheme (SIWES) in NIFFR and the Challenge of Skilled Fishery Extension Manpower Development in Nigeria. Journal of Agricultural Extension, (12): 1: 59-65

Jamison, T. (2015). 4 Reasons Effective Meetings are Important in the Workplace. Available on https://www.ctbizcenters.com/4-reasons-effective-meetings-are-important-in-a- workplace/

Jyostana M Shivankar. (2019). Occupation Structure in Urban Centers of Yavatmal District (Maharashtra State). Think India Journal, 22(38), 55-59. Retrieved from https://journals.eduindex.org/index.php/thinkindia/article/view/18722

Mahmood, A. (2017). Accessing the Brain Drain. Available on https://leadership.ng/2017/11/o2/assessing-braindrain/ Accessed in January 2018.

Mofesola, A. (2012). An Appraisal of the Student Industrial Work Experience Scheme (SIWES) in Federal College of Agriculture Akure, Greener Journal of Agricultural Sciences, 2 (4):162-166. 
Meratwal, D. J., \& Shanmugapriya, M. J. (2019). Total Quality Management: An Essential Tool to Efficacy of Business Strategy. Think India Journal, 22(15), 425-445. Retrieved from https://journals.eduindex.org/index.php/think- india/article/view/13285

Nag, A. (2016). 16 Factors that Lead to Poor Performance at the Workplace. Available on https://blog.commlabindia.com/elearning-design/negative-performance-factors>

Nigerian Bulletin, (2015). 10 Top Destinations in Ogun State. Available on https://www.nigerianbulletin.com/threads/10-top-destinations-in-ogun-state.133820/> Accessed on December 14, 2017

Nitin V. G. (2019). Globalization and Industrial Development in Thane District. Think India Journal, 22(38), 65-71. Retrieved from https://journals.eduindex.org/index.php/think-india/article/view/18724

Obi-Anike, H. O; Okafor, S. N and Adeleke, B. S. (2020). Internal Environment and Entrepreneurial-Venture Performance of Large Scale Enterprises (LSES) in Enugu, Nigeria. TEST Engineering E Management, 82: $1675-1684$

Odukoya, J.A., Omonijo, D.O., Olowookere, E.I., John, M., Atayero, A.A. (2019). Admission policy in universities: In search of empirical evidence. International Journal of Scientific and Technology Research, 8(12): 388-393

Olowu, A; Ijeoma E and Vanroose, A. (2019). The Nexus of Macroeconomic Policy and

Entrepreneurship Performance in West Africa. Academic Journal of Interdisciplinary Studies, 8(3): 263-270. Doi: 10.36941/ajis-2019-0024

Olugbenga, A. F. (2009). "Towards Effective SIWES Curriculum Development in Applied Sciences for Adequate Skills Utilization: A Case Study of the School of Applied Science, Nuhu Bamalli Polytechnic, Zaria”. Pacific Journal of Science and Technology. 10(1):234-239.

Onoyase, A. (2019). Causal Factors and Effects of Unemployment on Graduates of Tertiary Institutions in Ogun State South West Nigeria: Implications for Counselling. Journal of Educational and Social Research, 9(4), 119. Retrieved from http://www.richtmann.org/journal/index.php/jesr/article/view/10538

Omonijo, D. O., Olujobi, O. J., Anyaegbunam, M. C \& Adeleke V. A. (2018). Fundamental Human Rights, Polices of the Nigerian Private Universities and Safety of Students: A Critical Analysis. The Journal of Social Sciences Research, 4(12): 841-848. https://doi.org/10.32861/jssr.412.841.848.

Omonijo D. O., Anyaegbunam, M. C., Nnatu, O. B., Ejor, S., Victoria Ajibola, Adeleke, V. A., Oluwunmi, A. O. Olowooere, E. I and Agubo, C. (2019). The Review of the Student Industrial Work Experience Scheme (SIWES) in Four Selected Countries. Academic Journal of Interdisciplinary Studies, 8(3): 158-169. Doi: 10.2478/ajis-2019-0055

Pandey, S. (2019). Skill Based Education For Youth To Enhance Employability. Think India Journal, $22(15), 375-391$. Retrieved from https://journals.eduindex.org/index.php/think-india/article/view/13278

Peavler, R. (2017). Learn the Reasons for Business Budget Planning. Available on <https://www.thebalance.com/business-budget-planning-reasons-393029>

Rasool, F \& Botha, C. J. (2011). The nature, extent and effect of skills shortages on skills migration in South Africa. South Africa Journal of Human Resource Management, 9(1). doi:10.4102/sajhrm.v9i1.287

Saengchai, S; Joemsittiprasert, W and Jermsittiparsert, K. (2020). The Role of Educational Institutions in the Improvement of Engineering Education in Thailand: Mediating Role of Student's Motivation, Test Engineering and Management, 82: 3347-3358

Sheoran, A \& Amita, (2019). Strategic Management Issues and Opportunities in The Power Distribution Sector. Think India Journal, 22(15), 32-39. Retrieved from https://journals.eduindex.org/index.php/think-india/article/view/13238

Students Industrial Work Experience Scheme Retreat. (2015). Building Workplace Professional Values and Competencies of SIWES Students Supervisors. Retreat Organised for SIWES Personnel in Tertiary Institutions in Ogun-State Between Nov. $28^{\text {th }}$ and Dec. $1^{\text {st }} 2015$ at Topo-Badagry by the Industrial Training Fund, Abeokuta Area Office

Talabi, A. S. (2012). Employee's Training and Development for Optimum Productivity: The Role of Industrial Training Fund (ITF), Nigeria. Developing Country Studies, 2(4): 50-58

Ugwuanyi, C. F and Ezema, J. U. (2010). Challenges of Students' Industrial Work Experience Scheme (SIWES) in Library and Information Science in the ICT Environment. Library Philosophy and Practice, July, 1-6

Ukwueze, F. N. (2011). Impact of Student Work Industrial Experience Scheme (SIWES) on Development of Graduate Employability Skills. Nigerian Vocational Journal, 16(1): 118-124

Wodi, S. W and Dokubo, A. (2009). Appraisal of Students Industrial Work Experience Scheme (SIWES) in five Tertiary Institutions in Rivers State Nigeria: European Journal of Social Sciences, 7(3).

Zunaid, A. Turner, J.J. and Jiang, N. (2020). The effectiveness of a university internship programme: Student perspectives of stakeholder roles and responsibilities, Test Engineering and Management, 82: 868-883 